\title{
The Dynamic Impacts between International Trade and Silver-Copper Ratio in China 1825-1886
}

\author{
Ching Hsu \\ National Cheng-Chi University, Taiwan \\ Email: chinghssu@gmail.com
}

How to cite this paper: Hsu, C. (2018) The Dynamic Impacts between International Trade and Silver-Copper Ratio in China 1825-1886. Modern Economy, 9, 639-651. https://doi.org/10.4236/me.2018.94041

Received: February 27, 2018

Accepted: April 16, 2018

Published: April 19, 2018

Copyright $\odot 2018$ by author and Scientific Research Publishing Inc. This work is licensed under the Creative Commons Attribution-NonCommercial International License (CC BY-NC 4.0). http://creativecommons.org/licenses/by-nc/4.0/

\begin{abstract}
This study provides an alternative approach to analyze the linkages between the international trade and the domestic metal exchange rate in China during the $19^{\text {th }}$ century. I employ a dataset spanned from 1825 to 1886 to examine the dynamic intra- and inter-relationships between the domestic silver-copper ratios and the international trade in vector error correction methods. I obtain that a long-run relationship between the exports of tea and silk, the imports of opium, and the domestic silver-copper ratios existed in China. The silver-copper ratios Granger causes the imported opium, silver inflow and exported tea from China, but the international trade does not granger cause the silver-copper ratios. The impacts of impulse response function and variance decomposition are analyzed. The results suggest a more strong connection from the international trade and the domestic metal exchange rate than existent explorations.
\end{abstract}

\section{Keywords}

Vector Error-Correction Model, Economic History, Silver-Copper Ratio, Nineteenth Century, China, Trade

\section{Introduction}

Trades and metal coins advanced the economy of modern China and they made it worse in the $19^{\text {th }}$ century. Global trades separated China into two different fates after the mid- $19^{\text {th }}$ century, and tea and silk were the main goods exported to the world. The exported revenue of tea accounted for beyond 90 percent from 1825 to 1833 and around 50 percent from 1867 to 1886 , and the exported revenue of silk made up around 30 percent [1] [2]. Huge volumes of exports made trade surplus to China, and the tremendous silver inflow poured into the mone- 
tary system in China. The monetary system was contributed on the payment of copper coin and silver tael. The silver-copper ratios were unstable in the whole Qing dynasty. Daoguang Depression was one of the famous recessions in the Daoguang period (1820-1850). The fluctuation of silver-copper ratios led a chaos in the Chinese economy. Note that People used silver as currencies in China, but the silver was traded as commodities from Britain at the same time.

The recession of the silver mining in Latin America leads to a diminished import of silver in China, and the main cause of the outflow of silver is blamed to the trade deficits due to the huge imports of opium. Since the beginning of international trade, Fluctuations of the silver-copper ratios and the trade deficits winded up the economy of China. The silver-copper ratio means the exchange rate between wen (copper coin) and silver tael (a monetary standard like a thousand copper coin). The official silver-copper rate was 700 wen per silver tael. At 1820, the beginning of the Daoguang period, the ratio was 1226 wen per silver tael, and the ratio was raised to 2355 copper coin per silver tael at 1849 . The great depression led to a sharp decline of the economy of China. Interestingly, the monetary institution had different characters against most other countries in the period. First, the Qing government did not control the sovereignty of silver. Second, another payment tool prevailed in the southern China was the silver coin which is not valued by the weight but the face value, and there are many types of coins such as American pesos or Carolus. It was seen as the root to the varying exchange rates of copper and silver [3] [4]. Finally, silver was used as currencies in China, but it was traded as commodities in the world ${ }^{1}$. The liquidity preference theory seems reasonable, but the price has conflicts with the intrinsic value of the metal currencies. This issue is not negligible, but this study does not discuss the monetary theory because the different silver coins are able to convert to taels. This paper aims to unravel the relationship between the nominal rates and the international trade. This paper takes the advantages of the modern multivariate approach in discussing a classic topic of economic history in China. I employ a vector error correction model (VECM) to examine the dynamic intra- and inter-effects between the silver-copper ratios, the exports of tea and silk, and the imports of opium. However, the limit comes from the data. Through the difficulties collecting historical data, the small samples make biases on the VECM model analysis and the test of structure change in VECM, and the historical data are biased itself from the different resources. Section 2 discusses the literature review. Section 3 presents data and theoretical frameworks. Section 4 presents the Robustness check. Section 5 reports the results and the analysis. Section 6 concludes the whole paper.

\section{Literature Review}

Chen [1] employed the trade statistics covered from 1830 to 1870 to capture the role of China in the international trade. Lin $[5]^{2}$ obtained that the increased out-

${ }^{1}$ In this study, I use the tael as a benchmark, and the others can be transformed in fineness.

${ }^{2}$ The original edition is China Upside Down published in 1985. 
flow of silver was blamed for the recession of the market of tea and silk in the world before the Opium War, and therefore unbalanced the trade deficit. In her reference, China had a trade surplus since 1856 because the recounted exports exceed the recounted imports started. Lee [6] estimated the inflow of silver during 1645 to 1911 . He reviews and compares the data of the inflow of silver into China in the literature. Irigoin [4] emphasizes complex monetary institution is the main cause of the great depression in the Daoguang era. Because of the spread of Spanish American peso in the southern China as a usual payment after 1790, tremendous arbitrage of traditional silver tael dominate the pesos, and hence the result in huge opium imports.

The data from Qing are relatively abundant than the other dynasty, hence the economists are able to induce modern econometric approaches to provide different perspectives to understand the existed historical issues. Sng [7] discusses there is a principal-agent problem in the tax system in Qing Dynasty. Because of the large scale landscape, agents who collect tax are hard to be watched by the government and have no incentive to pay the total tax revenue to the government. He contributed a regression model to estimate how the distance affects the tax revenue. David [8] used asymmetric threshold error correction-mechanism model (ATECM) to investigate the power driving the first global integration in the $19^{\text {th }}$ century. Daniel et al. [9] provide the housing price during 1644 to 1840 , and they employed the ordinary least square (OLS) method to discuss the main fluctuations in housing prices. Ho and Lai [10] show that the exchange rate was the main chain of the silver price fluctuation from the world into China.

\section{Data and Theoretical Frameworks}

The historical data are separated from nineteenth century in China. Before the collapsed of East India Company (EIC), Morse [11] covered the data from 1635 to 1834 , and Hsiao [12] covered the data from 1864 to 1949 . Basically, many research of trade history are based on these two works. In this paper, the statistics of opium imports, silk exports are induced from Lin [5]. The data of tea exports are induced from Chen [2]. The data of silver-copper ratios are induced form Wang [13]. To reflect the living standard in China, I employed the data of rice price in China from Allen et al. [14] to depict the basic measurement of the goods. The data cover the period from 1825 to 1886 . Table 1 reveals the descriptive data of variables. The variables of tea, silk, and silver inflow are weighted in Chinese tan or picul and of opium is weighted in number of chests. One Chinese tan or picul is equal to $133.5 \mathrm{lbs}$. Tea is the main commodity exported from China to England. According to Hart [15], one chest can contain 100 catties which are equals to around $110 \mathrm{lbs}$. It shows the historical cognition that the extremely huge exports of tea may lead to the imports of opium. Meanwhile, the silver inflow shows an insufficiency of mine in the world.

Figure 1 shows the trends of exports and the silver-copper ratios. The exports of tea and silk and the imports of opium have similar trends before 1860, and the 
Table 1. Descriptive data of variables.

\begin{tabular}{cccccc}
\hline Variable & Obs & Mean & Std. Dev. & Min & Max \\
\hline Opium & 61 & $40,598.59$ & $27,060.71$ & 1000 & 83,000 \\
Tea & 61 & $154,000,000$ & $89,700,000$ & $22,600,000$ & $296,000,000$ \\
Silk & 61 & $4,131,209$ & $3,440,713$ & 8419 & $10,400,000$ \\
Silver Inflow & 61 & 116.2072 & 446.4134 & -945 & 942 \\
Silver-Copper Ratio & 61 & 1485.317 & 326.7109 & 919.9 & 2355 \\
Rice Price & 61 & 1.863181 & 0.5611559 & 0.975 & 3.286 \\
\hline
\end{tabular}

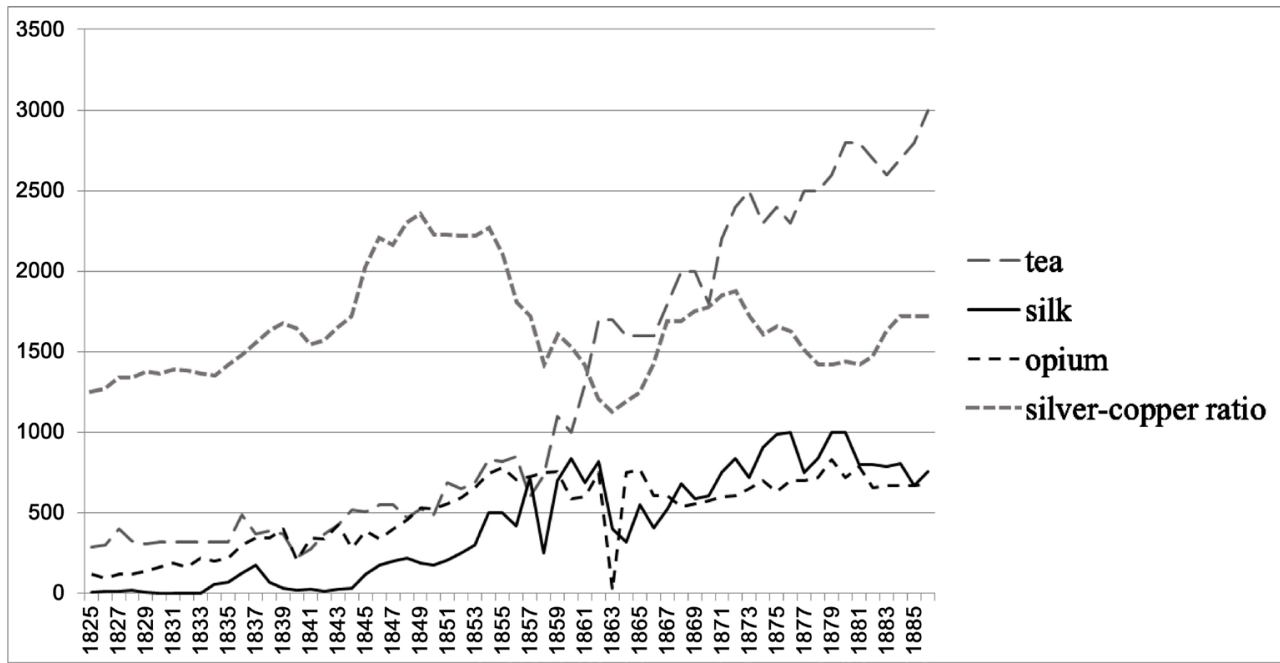

Sources: Lin [5], Chen [2] and Wang [13].

Figure 1. The trends of international trade of China and the silver-copper ratio.

silver-copper ratios have similar trends with either tea, silk, or opium. The possible hypothesis worked behind is the demand of silver. Exports of tea and silk did not compensate the trade deficits. There is a shortage of the supply of silver. Imports of opium made a huge silver outflow. Most of the scholars discussed the alternative causes of silver in different views such as increasing minting costs of copper, disordered institutions by circulating foreign silver coins, and the falling prices of copper [3] [4] [5] [13] [16]. However, trade and silver-copper ratios should be affected each other. I wonder how silver-copper ratios affected the volume of trade, and how much impact that the international trade affected the silver-copper ratios.

The silver-copper ratios and the traded goods increased since 1841 due to the Opium War. After 1861, the trends are similar except the exports of tea. Unit root tests examine whether the variables are stationary or not. Variables must be of stationary in vector autoregression (VAR) model. However, Granger and Newbold [17] discussed that if parameters are non-stationary in VAR model, the results have spurious regression. That leads the analysis to be not meaningful in economics, and Davidson, Hendry, Srba, and Yeo's [8] provided an ECM model to solve this problem. The results of unit root tests are that the silver inflow is 
$\mathrm{I}(0)$ variable and the silver-copper ratio, the exports of tea, the exports of silk, the imports of opium, and the rice price are I(1) variables by the Augmented Dickey-Fuller method, modified Dickey-Fuller $t$ test, and Phillips-Perron unit root test. Engle and Granger [18] obtain that combinations of I(1) variables are $\mathrm{I}(0)$ have long-run relationships named cointegration. Johansen [19] test represents there are three ranks in variables. To catch the dynamic interaction between variables, this paper employs a VECM model followed from Engle and Granger [18] to analyze the long-run and short-run relationships between the silver-copper ratios and International trade. The equation is as follows:

$$
\Delta y_{t}=v+\Pi y_{t-1}+\sum_{i=1}^{p-1} \Gamma_{i}+\varepsilon_{t}
$$

where $v$ is a $K \times 1$ vector of constant, $y_{t}$ is a $K \times 1$ vector of variables, $\Gamma_{i}$ is a $K \times K$ coefficient matrix and $\varepsilon_{t}$ is a $K \times 1$ vector of error term in assumption of white noise. $\Pi_{i}=\alpha \beta^{\prime}$ if $\Pi_{i}$ has a rank $0 \leq r<k$, where $\alpha$ means the short-run effect and $\beta$ means the long-run effect. Noted two special cases that this model are reduced to VAR model if $\Pi_{i}$ has zero rank, and the model has full rank if $\Pi_{i}$ has $K$ ranks. I can also rewrite (1) and with the trend term as follows:

$$
\Delta y_{t}=\alpha\left(\beta^{\prime} y_{t-1}+\mu+\rho t\right)+\sum_{i=1}^{p-1} \Gamma_{i} \Delta y_{t-i}+\gamma+\tau t+\varepsilon_{t}
$$

where $\tau=0$ to fit a restricted trend model. $\alpha$ is the adjustment speed, $\beta$ is the vector of cointegrated coefficients, $\mu$ and $\gamma$ are the constants, and $t$ is the trend term. The adjustment speed reflects how quick the error correction term will back to the equilibrium. If the equilibrium is reached, equals to zero. The first term on the right hand side reflects the long-run relationships. The second term on the right hand side is short-run relationships between variables. The advantages of VECM are able to observe the dynamic effect between the variables and the effects in the long-run and in the short-run. Moreover, the restricted trend controls the historical events such as the Opium War or the Taiping Rebellion so that the relationships in the long-run can truly be observed.

\section{Robustness Check}

This paper employs augment Dickey-Fuller unit root test and Phillips-Perron unit root test to check the stationary. Table 2 The variables of opium, tea, silk, silver-copper ratio and rice price are I(1) and of silver inflow is I(0). Table 3 reveals the rank equal to 1 which means one cointegrated equation in the model. Lütkepohl [20] indicates that the cointegrated ranks are allowed of I(0) variables $^{3}$, and therefore the cointegrated relationship includes silver inflow, which is also the $\mathrm{I}(0)$ variable. Noted that the restricted model is constructed to fit data and depict the trend term in the long-run relationship. Table 4 discloses the information criteria of VECM model. The 2 lagged period due to the

${ }^{3}$ Please see Lütkepohl (2005) p. 250. 
Table 2. Results of unit root tests.

\begin{tabular}{ccccc}
\hline \multirow{2}{*}{ Variables } & \multicolumn{2}{c}{ Augmented Dickey-Fuller } & \multicolumn{2}{c}{ Phillips-Perron } \\
\cline { 2 - 5 } & Origin & First Difference & Origin & First difference \\
\hline Opium & -2.255 & $-17.806^{*}$ & -1.698 & $-18.886^{*}$ \\
Tea & -1.34 & $-9.664^{*}$ & -1.29 & $-9.749^{\star}$ \\
Silk & -1.686 & $-11.274^{*}$ & -1.349 & $-12.126^{*}$ \\
Silver Inflow & $-4.471^{*}$ & $-15.34^{*}$ & -4.452 & $-15.938^{*}$ \\
Silver-Copper Ratio & -1.636 & $-7.254^{*}$ & -2.092 & $-7.325^{*}$ \\
Rice Price & -2.345 & $-10.825^{*}$ & -2.135 & $-1.127^{*}$ \\
\hline
\end{tabular}

Table 3. Results of cointegrated tests.

\begin{tabular}{cccccc}
\hline Max. rank & Parameters & LL & Eigenvalue & Trace statistics & Critical value 5\% \\
\hline 0 & 42 & -3407.0576 &. & 126.8662 & 114.9 \\
1 & 54 & -3383.4061 & 0.54542 & $79.5632^{*}$ & 87.31 \\
2 & 64 & -3367.2712 & 0.41599 & 47.2933 & 62.99 \\
3 & 72 & -3356.5066 & 0.3015 & 25.764 & 42.44 \\
4 & 78 & -3347.9965 & 0.24698 & 8.7439 & 25.32 \\
5 & 82 & -3344.1931 & 0.11907 & 1.1371 & 12.25 \\
\hline
\end{tabular}

Table 4. Information criteria of the VECM model.

\begin{tabular}{cccccccc}
\hline lag & LL & LR & df & p-value & AIC & HQIC & SBIC \\
\hline 0 & -3545.3 & & & & 122.457 & 122.54 & 122.67 \\
1 & -3281.3 & 527.85 & 36 & 0 & 114.597 & 115.179 & $116.089^{\star}$ \\
2 & -3230.1 & 102.39 & 36 & 0 & $114.073^{*}$ & $115.153^{*}$ & 116.844 \\
3 & -3203.5 & 53.211 & 36 & 0.032 & 114.397 & 115.975 & 118.447 \\
4 & -3174 & $58.997^{*}$ & 36 & 0.009 & 114.621 & 116.697 & 119.95 \\
\hline
\end{tabular}

minimal AIC. ${ }^{4}$

\section{Results}

Table 5 reports the coefficients of the cointegrated equation. The variables of opium, tea, silk and silver-copper ratios are significant in the long-run relationship. The value of tea and opium is above the equilibrium, and the values of silk and silver-copper ratio are under the equilibrium. The adjustment speed shows that tea and opium will fall back toward the silk and the silver-copper ratio levels, and silk and the silver-copper ratio will rise toward the tea and the opium levels at the same time. ${ }^{5}$

${ }^{4}$ MacGregor [21] mentioned that even a very fast clipper in the route of The Great Race needs 99 days from China to Britain. Since the information were slower, 2 years lag make senses for dynamic transmissions between variables.

${ }^{5}$ In the mid-nineteenth century, the historical events such as Taiping rebellion or Nien rebellion led to influences in the Chinese economy. However, the events cannot be captured completely since the limitation of the model. The VECM model describes the average behaviors in the whole period so that the historical events are hard to be caught individually. In this study, the setting of the model the trend term depicts the events with time. It is expected to solve the problem in the future investigation. 
The long-run linkages provide alternative channels to observe the drain of silver problem. Wang [13] discussed the reasons of the Douguang Depression. There are many reasons led to the Douguang Depression such as minting costs, fluctuated silver-copper ratios, etc. However, the reasons were discussed individually. The long-run equilibrium is quite different. The cointegrated relationship gives a mechanism that if the exports of tea increased, the imports of opium, the exports of silk, and the silver-copper ratios would adjust the levels at the same time (Table 6).

Lin [5] discussed that the trade deficits were not made up due to the recession of tea and silk market in the world and the drain of silver inflow before the Opium War. The results not only support her study but also provide a long-run co-movement between the imports of opium, the exports of tea and silk, and the silver-copper ratios which is a longer period than Lin [5]. The long-run equilibrium is similar to a stable path and brings the trade and the silver-copper ratios to a steady level. However, why is there equilibrium for the trade and silver-copper ratios? It is obvious that China needed a large demand for silver, the exports of tea and silk continued, and the imports of opium pushed out the stock of silver in the China. The silver-copper ratios fluctuated in between. The results suggest a circle inside the Chinese economy, and this mechanism continued to

Table 5. The coefficients of the cointegrated equation from 1825 to 1886.

\begin{tabular}{cccc}
\hline & Coefficient cointegarted equation & & \\
\hline & Coefficient & Std. Err. & p-value \\
\hline Opium & 1 & - & - \\
Tea & $3.815 \mathrm{E}-04$ & $8.870 \mathrm{E}-05$ & $0.000^{*}$ \\
Silk & -0.013 & 0.002 & $0.000^{*}$ \\
Silver Inflow & -4.658 & 4.552 & 0.306 \\
Silver-Copper Ratio & -18.727 & 7.999 & $0.019^{*}$ \\
Rice Price & -12.792 & 5738.177 & 0.998 \\
Trend & -645.387 & 418.021 & 0.123 \\
Constant & -8072.218 & - & - \\
\hline
\end{tabular}

Table 6. The coefficients of the adjustment speed.

\begin{tabular}{cccc}
\hline & Adjustment speed & & \\
\hline Opium & Coefficient & Std. Err. & p-value \\
Tea & -0.310 & 0.120 & $0.010^{\star}$ \\
Silk & -320.641 & 149.719 & $0.032^{\star}$ \\
Silver Inflow & 24.811 & 12.350 & $0.045^{\star}$ \\
Silver-Copper Ratio & -0.009 & 0.003 & $0.005^{*}$ \\
Rice Price & 0.004 & 0.001 & $0.000^{\star}$ \\
& 0.000 & 0.000 & 0.187 \\
\hline
\end{tabular}


Table 7. The results of granger causality ${ }^{6}$.

\begin{tabular}{|c|c|c|c|c|c|c|}
\hline \multicolumn{7}{|c|}{ Granger Causality Test } \\
\hline & Opium & Tea & Silk & Silver Inflow & $\begin{array}{c}\text { Silver-Copper } \\
\text { Ratio }\end{array}$ & Rice Price \\
\hline Opium & $\begin{array}{l}\mathrm{F}=0 \\
(1.000)\end{array}$ & $\begin{array}{l}F=1.30 \\
(0.2798\end{array}$ & $\begin{array}{l}F=4.55^{*} \\
(0.0148)\end{array}$ & $\begin{array}{l}F=4.08^{*} \\
(0.0221)\end{array}$ & $\mathrm{F}=0.38(0.684)$ & $\begin{array}{l}F=0.13 \\
(0.8768)\end{array}$ \\
\hline Tea & $\begin{array}{l}\mathrm{F}=3.19^{*} \\
(0.0487)\end{array}$ & $\begin{array}{l}\mathrm{F}=0 \\
(1.000)\end{array}$ & $\begin{array}{l}F=2.07 \\
(0.1356)\end{array}$ & $\begin{array}{l}F=1.16 \\
(0.3200)\end{array}$ & $\mathrm{F}=0.44(0.647)$ & $\begin{array}{l}F=1.83 \\
(0.1700)\end{array}$ \\
\hline Silk & $\begin{array}{c}\mathrm{F}=3.57^{\star} \\
(0.0349)\end{array}$ & $\begin{array}{c}\mathrm{F}=2.74^{\star *} \\
(0.0731)\end{array}$ & $\begin{array}{l}F=0 \\
(1.000)\end{array}$ & $\begin{array}{c}\mathrm{F}=3.96^{*} \\
(0.0247)\end{array}$ & $\begin{array}{c}F=5.20^{*} \\
(0.0086)\end{array}$ & $\begin{array}{l}F=0.77 \\
(0.4686)\end{array}$ \\
\hline Silver Inflow & $\begin{array}{l}F=1.55 \\
(0.2210)\end{array}$ & $\begin{array}{l}F=0.30 \\
(0.7386)\end{array}$ & $\begin{array}{l}F=1.43 \\
(0.2475)\end{array}$ & $\mathrm{F}=0(1.000)$ & $\begin{array}{l}F=0.57 \\
(0.2163)\end{array}$ & $\begin{array}{l}F=1.57 \\
(0.2173)\end{array}$ \\
\hline $\begin{array}{c}\text { Silver-Copper } \\
\text { Ratio }\end{array}$ & $\begin{array}{l}F=1.01 \\
(0.3711)\end{array}$ & $\begin{array}{l}F=0.09 \\
(0.9122)\end{array}$ & $\begin{array}{l}F=0.79 \\
(0.4571)\end{array}$ & $\begin{array}{c}\mathrm{F}=2.95^{\star *} \\
(0.0620)\end{array}$ & $\begin{array}{l}F=0 \\
(1.000)\end{array}$ & $\begin{array}{l}F=1.54 \\
(0.2229)\end{array}$ \\
\hline Rice Price & $\begin{array}{c}\mathrm{F}=2.44^{* *} \\
(0.0959)\end{array}$ & $\begin{array}{l}F=0.52 \\
(0.5958)\end{array}$ & $\begin{array}{l}F=8.59^{*} \\
(0.0006)\end{array}$ & $\begin{array}{l}F=0.44 \\
(0.6454)\end{array}$ & $\begin{array}{c}F=5.35^{\star} \\
(0.0074)\end{array}$ & $\begin{array}{l}F=0 \\
(1.000)\end{array}$ \\
\hline
\end{tabular}

${ }^{*}$ and ${ }^{* *}$ denote significance level at $1 \%, 5 \%$.

the end of the use of silver.

Table 7 shows the results of Granger causality. The tea and the silk do not Granger-cause the opium are rejected. The opium Granger causes the silk. It is known that the huge demand for tea from British were the main reasons for the international trade. The intra-actions within the international trade were obvious, but the tea only affected opium. The rise prices Granger cause silk. The silk and the rice price Granger causes the silver-copper ratio. The exports of tea and silk led to an increased demand of opium. For Britain, the huge demand for tea induces an incentive to supply more opium to China. Nevertheless, the change of opium does not affect the exports of tea due to the strong addiction to opium. While the exports of silk that causes the exports of tea may result from the limit of transportation.

The impulse response functions show the effect that the change when the impulse variables arise to the response variables. Figure 2 depicts the impulse response results. The shock of tea and silk leads to a decreasing response of opium at first period. The response of opium increases and converges around -0.0002 when the shocks come from tea or silk. The response of silk increases and converges to 30 when the shock comes from opium. The response of silk increases in the first period, and it decreases in the following period when the shock comes from the rice price. The silver-copper ratios go down when the shock comes from the silk. The silver-copper ratios increase slightly in the first period, and then decline sharply when the shock comes from the rice price. The response of silk is bigger than of opium. However, the quantities consumed between silk and opium were different. The shocks form silk to opium transmitted ${ }^{6}$ Numbers under the $\mathrm{F}$ statistics are p-values. ${ }^{*}$ is the confidential level $5 \%$ and ${ }^{\star *}$ is the confidential level $10 \%$. 


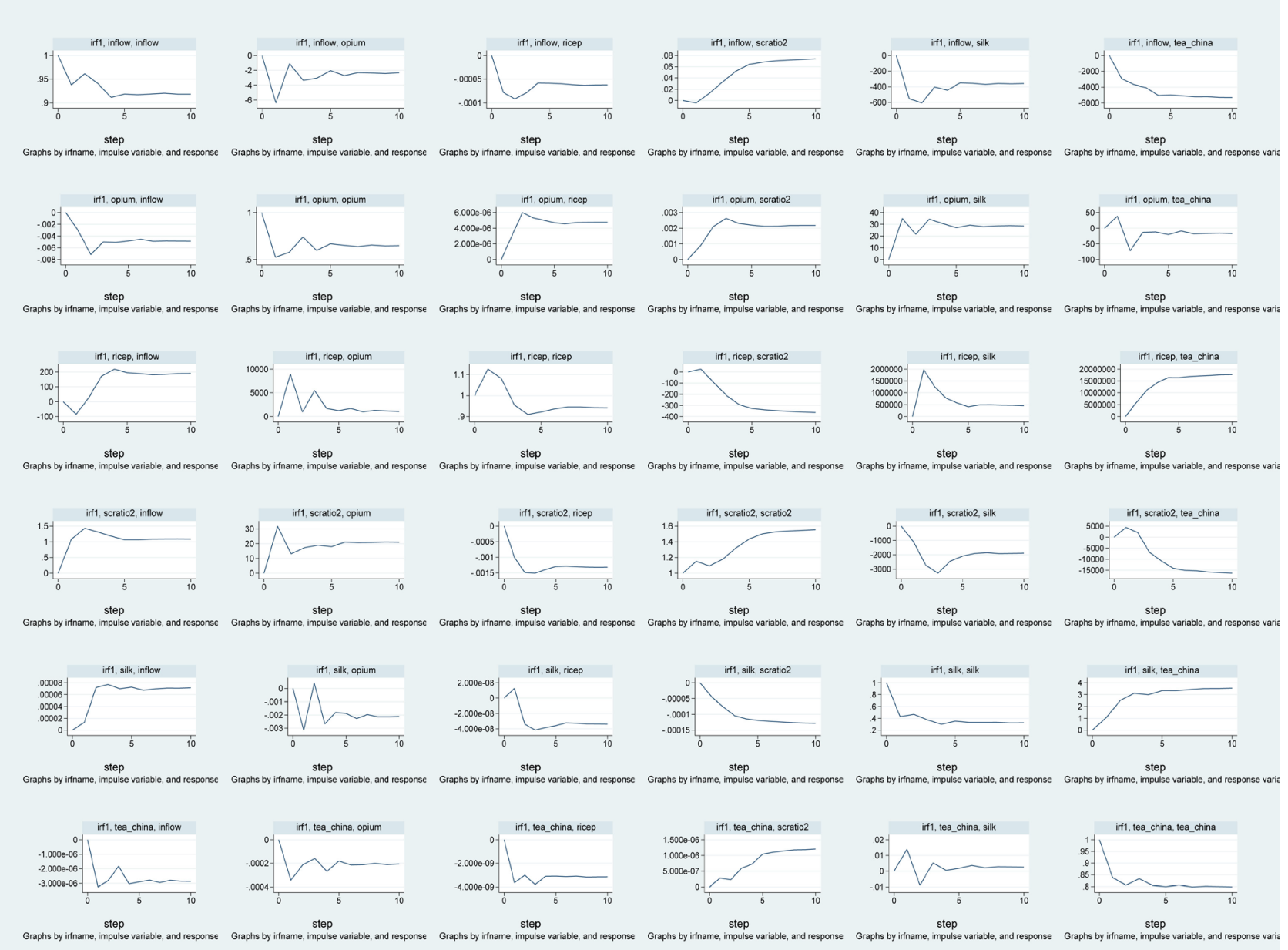

Figure 2. Results of impulse response function.

to a huger power in the second period. Silk was durable goods between the three goods so that the elasticity of silk must be smaller than the others.

To assess the volatility of one variable transmitted from the other variables, I employ a method of variance decomposition to measures each type of volatility to the forecast error variance [22]. Table 8 reports the variance decomposition of opium, tea, silk, and silver-copper ratio. Silk explain the variance of opium in the second highest level and the variance of silk in the highest level. It is interesting that silk plays a more important role than tea in the volatility part. Moxham [23] mentioned that from the 1940s to 1950s, the exports of tea from China still maintain stable with the wars or turmoil. The reason is that the tea is steadily increasing with time even in the historical events such as Taiping rebellion. The silver-copper ratio explains the volatility of silk at the third highest level as well as the rice price. The results illustrate the domestic nominal factors affects the exports of silk. A possible exposition is the competition on planting the mulberry trees or the rice. Mulberry leaves feed silkworms, and these are the resources of silk. There is no competition on the mulberry trees and the tea trees in China because the planting area of tea locates on a higher elevation. 
Table 8. Results of variance decomposition.

\begin{tabular}{|c|c|c|c|c|c|c|}
\hline \multicolumn{7}{|c|}{ opium } \\
\hline period & opium & tea & silk & inflow & $\begin{array}{l}\text { silver-copper } \\
\text { ratio }\end{array}$ & rice price \\
\hline 0 & 0 & 0 & 0 & 0 & 0 & 0 \\
\hline 1 & 1.000 & 0.020 & 0.182 & 0.003 & 0.008 & 0.000 \\
\hline 2 & 0.962 & 0.051 & 0.341 & 0.006 & 0.011 & 0.064 \\
\hline 3 & 0.920 & 0.082 & 0.392 & 0.008 & 0.009 & 0.123 \\
\hline 4 & 0.886 & 0.108 & 0.413 & 0.008 & 0.024 & 0.162 \\
\hline 5 & 0.858 & 0.132 & 0.422 & 0.008 & 0.049 & 0.187 \\
\hline 6 & 0.835 & 0.151 & 0.426 & 0.008 & 0.076 & 0.204 \\
\hline 7 & 0.815 & 0.168 & 0.427 & 0.008 & 0.102 & 0.217 \\
\hline 8 & 0.796 & 0.182 & 0.427 & 0.008 & 0.126 & 0.225 \\
\hline 9 & 0.778 & 0.195 & 0.425 & 0.007 & 0.146 & 0.232 \\
\hline 10 & 0.760 & 0.206 & 0.422 & 0.007 & 0.163 & 0.237 \\
\hline \multicolumn{7}{|c|}{ tea } \\
\hline period & opium & tea & silk & inflow & $\begin{array}{c}\text { silver-copper } \\
\text { ratio }\end{array}$ & rice price \\
\hline 0 & 0 & 0 & 0 & 0 & 0 & 0 \\
\hline 1 & 0.000 & 0.980 & 0.015 & 0.051 & 0.031 & 0.027 \\
\hline 2 & 0.013 & 0.939 & 0.054 & 0.054 & 0.038 & 0.022 \\
\hline 3 & 0.032 & 0.901 & 0.077 & 0.056 & 0.036 & 0.027 \\
\hline 4 & 0.052 & 0.867 & 0.093 & 0.057 & 0.032 & 0.034 \\
\hline 5 & 0.070 & 0.837 & 0.106 & 0.058 & 0.027 & 0.039 \\
\hline 6 & 0.086 & 0.810 & 0.116 & 0.059 & 0.022 & 0.044 \\
\hline 7 & 0.101 & 0.787 & 0.124 & 0.059 & 0.019 & 0.048 \\
\hline 8 & 0.115 & 0.766 & 0.132 & 0.059 & 0.016 & 0.051 \\
\hline 9 & 0.128 & 0.748 & 0.138 & 0.060 & 0.014 & 0.054 \\
\hline 10 & 0.141 & 0.731 & 0.144 & 0.060 & 0.012 & 0.056 \\
\hline \multicolumn{7}{|c|}{ silk } \\
\hline period & opium & tea & silk & inflow & $\begin{array}{c}\text { silver-copper } \\
\text { ratio }\end{array}$ & rice price \\
\hline 0 & 0 & 0 & 0 & 0 & 0 & 0 \\
\hline 1 & 0.000 & 0.000 & 0.803 & 0.060 & 0.014 & 0.026 \\
\hline 2 & 0.007 & 0.007 & 0.540 & 0.056 & 0.075 & 0.082 \\
\hline 3 & 0.009 & 0.014 & 0.432 & 0.055 & 0.123 & 0.122 \\
\hline 4 & 0.009 & 0.019 & 0.376 & 0.053 & 0.156 & 0.149 \\
\hline 5 & 0.008 & 0.023 & 0.342 & 0.053 & 0.176 & 0.167 \\
\hline 6 & 0.008 & 0.026 & 0.319 & 0.052 & 0.187 & 0.181 \\
\hline 7 & 0.008 & 0.029 & 0.301 & 0.051 & 0.193 & 0.191 \\
\hline
\end{tabular}


Continued

\begin{tabular}{|c|c|c|c|c|c|c|}
\hline 8 & 0.008 & 0.031 & 0.288 & 0.051 & 0.196 & 0.199 \\
\hline 9 & 0.008 & 0.033 & 0.277 & 0.050 & 0.197 & 0.206 \\
\hline 10 & 0.009 & 0.035 & 0.267 & 0.050 & 0.197 & 0.212 \\
\hline \multicolumn{7}{|c|}{ silver-copper ratio } \\
\hline period & opium & tea & silk & inflow & $\begin{array}{c}\text { silver-copper } \\
\text { ratio }\end{array}$ & rice price \\
\hline \multicolumn{7}{|c|}{ continued } \\
\hline 0 & 0 & 0 & 0 & 0 & 0 & 0 \\
\hline 1 & 0.000 & 0.000 & 0.000 & 0.000 & 0.945 & 0.028 \\
\hline 2 & 0.010 & 0.001 & 0.006 & 0.000 & 0.838 & 0.020 \\
\hline 3 & 0.022 & 0.001 & 0.008 & 0.000 & 0.745 & 0.021 \\
\hline 4 & 0.033 & 0.000 & 0.010 & 0.000 & 0.646 & 0.025 \\
\hline 5 & 0.041 & 0.000 & 0.010 & 0.001 & 0.552 & 0.028 \\
\hline 6 & 0.048 & 0.000 & 0.010 & 0.001 & 0.472 & 0.031 \\
\hline 7 & 0.054 & 0.000 & 0.010 & 0.001 & 0.406 & 0.034 \\
\hline 8 & 0.059 & 0.000 & 0.010 & 0.001 & 0.352 & 0.037 \\
\hline 9 & 0.062 & 0.001 & 0.010 & 0.001 & 0.310 & 0.039 \\
\hline 10 & 0.066 & 0.001 & 0.009 & 0.001 & 0.276 & 0.041 \\
\hline
\end{tabular}

\section{Conclusions}

The globalization not only made a growth but also brought a lot of economic problems in China in the mid-19th century. The exports of tea and silk made tremendous influx of silver, but it also resulted in the imports of opium and the fluctuation of silver-copper ratios. The puzzle of outflowed silver in the mid-19 century leads numerous scholars to debate why Chinese economy has fallen, e.g. Lin [5], von Glahn [3], Irigion [4]. This paper provides an alternative discuss on the relationship between the international trade and the silver-copper ratios by contributing a VECM model. I obtain the long-run cointegrated relationship between the imports of opium, the exports of tea and silk, and the silver-copper ratios from 1825 to 1886 . Interestingly, there was a long-run relationship even China experienced many wars or turmoil. The possible presumptions are the limits in the model and the immense demand of tea from Britons.

The Granger causality tests show that the tea and the silk Granger cause the opium. It supports the history that the huge exports of tea and silk from China made large trade deficits to Britain. In order to support the demand of tea in the Britain market, The British East India Company exports opium from India to China. The silk and the rice price Granger cause the silver-copper ratios, and the result is related to a competition on planting the mulberry trees or the rice fields. However, the silver-copper ratios do not Granger cause the trade term. The impulse response functions reveal the short-run impact from impulse variables and the variance decomposition shows how does the volatility can be explained by 
the other variables. The econometric analysis provides a useful analysis, but it also gives us some problems that should be carefully discussed. The model illustrates average behaviors in the all period, and the historical events may not be deliberated completely. For instance, the sharp decline of imports of opium before the Opium War is hard to depict.

\section{References}

[1] Chen, T.-Y. (1984) Investigations China's Trade Based on the Triangle Trade between China, British and India. Essays in Chinese Maritime History, I, 130-173.

[2] Chen, T.-Y. (2013) The Development of Modern Chinese Tea. China Renmin University Press Co., LTD., Beijing.

[3] Von Glahn, R. (2007) Foreign Silver Coins in the Market Culture of 19th Century China. International Journal of Asian Studies, 4, 51-78. https://doi.org/10.1017/S1479591407000575

[4] Irigoin, M.A. (2013) A Trojan Horse in Daoguang China? Explaining the Flows of Silver in and out of China. Economic History Working Papers No. 173/13, London School of Economics and Political Science, London.

[5] Lin, M. (2006) China Upside Down: Currency, Society, and Ideologies, 1808-1856. Harvard University Asia Center, Cambridge. https://doi.org/10.2307/j.ctt1tg5q75

[6] Lee, L.-S. (2009) Estimating the Yearly Amount of Silver Inflow during the Ching Dynasty in China (1645-1911). Journal of Humanities and Social Sciences, 5, 31-58.

[7] Sng, T.H. (2014) Size and Dynastic Decline: The Principal-Agent Problem in Late Imperial China, 1700-1850. Explorations in Economic History, 54, 107-127. https://doi.org/10.1016/j.eeh.2014.05.002

[8] Davidson, J.E., Hendry, D.F., Srba, F. and Yeo, S. (1978) Econometric Modelling of the Aggregate Time-Series Relationship between Consumers' Expenditure and Income in the United Kingdom. The Economic Journal, 88, 661-692. https://doi.org/10.2307/2231972

[9] Raff, D., Wachter, S. and Yan, S. (2013) Real Estate Prices in Beijing, 1644 to 1840. Explorations in Economic History, 50, 368-386. https://doi.org/10.1016/j.eeh.2012.10.003

[10] Ho, T.K. and Lai, C.C. (2013) Silver Fetters? The Rise and Fall of the Chinese Price Level 1928-34. Explorations in Economic History, 50, 446-462. https://doi.org/10.1016/j.eeh.2013.03.001

[11] Morse, H.B. (1926) Chronicles of East India Company Trading to China, 1635 to 1835. Vol. IV. Clarendon Press, Oxford.

[12] Hsiao, L.L. (1974) China's Foreign Trade Statistics, 1864-1949 (No. 56). Harvard University Asia Center, Cambridge.

[13] Wang, H. (2015) The Price Standard: The Monetary Value Comparison in Qing Dynasty. SDX Joint Publishing Company, Chicago.

[14] Allen, R.C., Bassino, J.P., Ma, D., Moll-Murata, C. and Van Zanden, J.L. (2011) Wages, Prices, and Living Standards in China, 1738-1925: In Comparison with Europe, Japan, and India. The Economic History Review, 64, 8-38. https://doi.org/10.1111/j.1468-0289.2010.00515.x

[15] Hart, R. (1881) Opium in China: How Many Smokers Does the Foreign Drug Supply? Journal of the Statistical Society of London, 44, 743-50.

[16] Lin, M.H. (2015) The Devastation of the Qing Mints, 1821-1850. In: Leonard, J.K. 
and Theobald, U., Eds., Money in Asia (1200-1900): Small Currencies in Social and Political Contexts, Brill Co., Leiden, 155-187.

[17] Granger, C.W. and Newbold, P. (1974) Spurious Regressions in Econometrics. Journal of Econometrics, 2, 111-120. https://doi.org/10.1016/0304-4076(74)90034-7

[18] Engle, R.F. and Granger, C.W. (1987) Co-Integration and Error Correction: Representation, Estimation, and Testing. Econometrica: Journal of the Econometric Society, 55, 251-276. https://doi.org/10.2307/1913236

[19] Johansen, S. (1991) Estimation and Hypothesis Testing of Cointegration Vectors in Gaussian Vector Autoregressive Models. Econometrica: Journal of the Econometric Society, 59, 1551-1580. https://doi.org/10.2307/2938278

[20] Lütkepohl, H. (2005) New Introduction to Multiple Time Series Analysis. Springer Science \& Business Media, Berlin. https://doi.org/10.1007/978-3-540-27752-1

[21] MacGregor, D.R. (1983) Tea Clippers: Their History and Development, 1833-1875. US Naval Institute Press, Annapolis.

[22] Campbell, J.Y. (1990) A Variance Decomposition for Stock Returns. No. w3246, National Bureau of Economic Research, Cambridge. https://doi.org/10.3386/w3246

[23] Moxham, R. (2004) Tea: Addiction, Exploitation and Empire. Running Press Book Pub., Philadelphia. 